\title{
LA PROFESSÓ QUE VA PER DINS: UN ESTUDI ANTROPOLÒGIC DE LA SETMANA SANTA TARRAGONINA A TRAVÉS DELS PORTANTS A ESPATLLES
}

\author{
Adolf Quetcuti I FERRER \\ Doctorand en Antropologia i Comunicació \\ Universitat Rovira i Virgili \\ adolfquetcuti@gmail.com
}

RESUM: Aquest article pretén analitzar els diferents elements que identifiquen un grup de persones que participen en les professons de la Setmana Santa de Tarragona i són coneguts amb el nom de portants. Majoritàriament amagats sota les faldilles dels anomenats misteris (representacions escultòriques de la passió i mort de Jesús de Natzaret), aquest collectiu abraça múltiples motivacions que van més enllà del caràcter religiós que se li pressuposa. En un món marcat per la transformació de la religiositat, la transmissió familiar, el gènere o la identitat local emergeixen com a elements importants que motiven i identifiquen la seva participació, que a la vegada s'emmarca sota una forta identitat de grup que s'adquireix a través d'uns rituals que actuen com a elements de socialització.

PARAUles ClaU: Setmana Santa; identitat; religiositat; ritual.

* El terme professó és una forma alterada, per etimologia popular i influència de professio -ionis (acció de professar), de la paraula processó. En aquest article, preferentment, s'ha fet servir aquesta variant popular molt utilitzada en l'argot popular de la ciutat de Tarragona. 
ABSTRACT: This article analyses the elements that identify a group of people, known as "portants", who take part in the Holy Week processions of Tarragona. Mostly hidden under the cloths that drape from the so-called "misteris" (sculptural representations of the passion and death of Jesus of Nazareth), this group of people have multiple motivations that go beyond the pressuposed religious beliefs. In a world marked by the transformation of religiosity, family transmission, gender or local identity emerge as important elements that motivate and identify their participation, which is at the same time, framed by a strong group identity that is acquired through rituals that act as elements of socialization.

KEYWORDS: Holy Week; identity; religiosity; rituals. 


\section{Introducció}

Tot i que en diferents regions de l'Estat espanyol la Setmana Santa representa un conjunt de dies amb un significat turístic i de descans molt similar al de les vacances d'estiu, el cert és que, en moltes altres localitats, es defineix com una festa popular que emmarca rituals, vivències i escenificacions socials molt diverses que, pels seus orígens marcadament cristians, facilment associem a una visió religiosa unitària.

És en aquest sentit que, segurament, una de les coses que més ens cridaran l'atenció és que, en un moment en què religions hegemòniques com el cristianisme han perdut el paper simbòlic que els era atorgat, hi hagi un nombre important de persones que participin en determinats actes amb un alt simbolisme d'aquesta confessionalitat.

I és que manifestacions populars com les de la Setmana Santa no només tenen un sentit catequètic vinculat a la religió sinó que, simultàniament, també funcionen com a reproducció d'identitats i identificacions collectives que van més enllà de la qüestió purament religiosa.

Així doncs, fent un parallelisme entre la ubicació dels portants que duen a espatlles les imatges religioses de la professó, i els motius i les creences interiors que els porten a participar en aquesta manifestació, aquest article titulat "La professó que va per dins" pretén ser una síntesi d'un estudi més extens que es pregunta per les diferents significacions que en l'actualitat prenen algunes manifestacions populars d'origen cristià.

La Setmana Santa de Tarragona habitualment ha estat un fenomen estudiat des d'una temàtica històrica, religiosa o artística que, sovint, ha descuidat el seu vessant més social. Com a exemple que reflecteix aquesta visió, tan sols caldria mirar les nombroses publicacions anuals que elaboren les diferents associacions per adonar-se que l'aspecte social d'aquesta manifestació és una qüestió poc tractada.

Per mitjà d'una metodologia qualitativa en què principalment s'ha fet ús de l'entrevista semidirigida, aquesta recerca té l'objectiu d'analitzar la realitat sociocultural d'aquesta manifestació des de l'antropologia. És, en definitiva, una invitació a apropar-se a un fenomen tan polièdric que, més enllà del valor artístic i religiós, en consideri també el caràcter social sense prejudicis ni prismes ideològics. 
En total s'han realitzat vint entrevistes a portants que estan en actiu i s'ha procurat que la mostra sigui el màxim de representativa pel que fa a les edats i a l'experiència. En aquest sentit, trobem persones que van dels 21 als 57 anys i poden tenir entre 2 i 29 anys d'experiència. La mostra també ha procurat recollir les diferents entitats que tenen passos a espatlles.

Pel que fa a l'observació, d'una banda ha estat distant en aquells casos en què s'ha assistit a assajos de confraries sense mantenir cap contacte directe amb els participants i de l'altra, participant (en un cas concret), en què, a més de desenvolupar la tasca de portant, també s'han compartit diferents espais de socialització com són, per exemple, els esmorzars o els sopars.

Per tant, acostar-se a la realitat social de la Setmana Santa implica donar veu als protagonistes, perquè siguin ells mateixos els qui mostrin i posin en joc diferents elements que permetin a cada persona interessada en aquesta temàtica poder elaborar la seva interpretació més enllà dels tòpics. Donar veu a les persones és també un intent de deixar enrere les opinions únicament fonamentades en interpretacions que no tenen en compte l'opinió dels participants.

Força vegades les interpretacions d'aquesta manifestació juguen a cavall de dues polaritats i molts cops podríem preguntar-nos si no existeixen dues Setmanes Santes en parallel: la religiosa i la folklòrica. Les avui tan presents xarxes socials a cops ens brinden l'oportunitat de poder fer una etnografia digital que mostra bé aquests dos vessants. El 19 d'abril del 2014, a l'edició digital del Diari de Tarragona hi apareixia aquesta opinió fruit d'un article que en va generar moltes d'altres: "Si parlem de fe cristiana, no hi ha millor forma de practicar-la que anant a missa cada diumenge. Les processons de Setmana Santa, almenys la de Tarragona, estan plenes d'hipocresia i molta façana. Tothom busca sortir bé a les fotos, però molt poca gent és conscient de participar en un acte religiós.. En un sentit contrari, hi ha persones que ho veuen amb un molt de contingut religiós, cosa que els porta a allunyar-se d'aquesta celebració, inclús quan la vivència se'ls ha transmès de forma familiar. Com a exemple trobem aquest fragment en un grup privat de WhatsApp que pren per nom Tertúlia Confrare: "S'han perdut masses anys de no promoció de la Setma- 
na Santa. Els meus fills no volen saber-ne res, i no serà que a casa hi ha algú que la viu tot l'any. La filla gran diu que la Setmana Santa no està de moda, no té ganxo i, a més, que no hi creu. En canvi, està impacient que arribi el Carnaval..."

Hi ha moments representatius de la Setmana Santa tarragonina que realment denoten aquestes dues polaritats. D'una banda, trobem aquella manifestació íntima i recollida que es plasma en el viacrucis de les $6 \mathrm{del}$ matí, ${ }^{1}$ en la lectura de les Set Paraules ${ }^{2}$ a la capella de Sant Magí o en les tradicionals visites als monuments ${ }^{3}$ del Dijous Sant. De l'altra, ens trobem amb manifestacions que tenen una orientació més propera a l'espectacle o, si es vol, que expressen menys recolliment com la coneguda recollida dels passos ${ }^{4}$ durant la tarda del Divendres Sant abans de començar la professó. És el que podríem definir, manllevant la frase a un illlustre poeta tarragoní com Ramon Comas: "Solemnes processons i shows ben atrevits."

El conjunt de la recerca inclou també una etnografia fotogràfica de la qual se'n mostren alguns exemples. Aquesta mostra visual es divideix en dues orientacions diferents que he volgut definir com a conduïda i com a lliure.

Per conduïda s'entén el recull fotogràfic que, amb l'ajuda desinteressada de l'amic Quim Vendrell Moreno, professional de la fotografia, es fa de cada una de les persones entrevistades. L'objectiu és elaborar una mostra visual dels participants en la Setmana Santa, és a dir, ensenyar les cares que viuen la "professó per dins" (sota els passos) i, si pot ser, en un context professional o de lleure que no necessàriament estigui vinculat a la Setmana Santa; una mostra visual que, a través de la multiplicitat de perfils,

\footnotetext{
I El segon acte amb més participació de gent que es caracteritza per una pràcticament absència d'espectadors. S'inicia amb un sermó conegut com "de la bufetada" a la Catedral i posteriorment es recorren els principals carrers de la Part Alta de la ciutat tot resant les catorze estacions de les qual es compon el viacrucis cristià.

2 Acte en què set oradors fan una reflexió personal a través de les set paraules que Crist va pronunciar a la creu.

3 Els monuments que fan diverses esglésies de la ciutat són custòdies que guarden el Santíssim Sagrament (cos de Crist) i estan exposades perquè la gent hi vagi a fer les oracions de forma íntima.

4 Acte en què el Divendres Sant a la tarda els armats van a buscar els passos que formen part de la Setmana Santa de Tarragona (que estan repartits en diferents punts de la ciutat) i els acompanyen a la plaça del Rei per iniciar la coneguda professó del Sant Enterrament.
} 
vol presentar els participants en la situació de communitas, concepte descrit per Victor Turner.

Per lliure entenc el recull de fotografies que he demanat que facin algunes persones entrevistades amb els mòbils personals d'aquells moments que per a ells són representatius de la Setmana Santa. L'objectiu és poder enregistrar, gràficament i de primera mà, alguns dels moments que en les entrevistes s'han revelat com els més representatius per als portants. A la vegada, es pensa com una oportunitat per redescobrir altres vivències i espais que els entrevistats consideren interessants de la seva participació.

\section{Alguns apunts sobre la Setmana Santa tarragonina}

La professó de Tarragona està documentada des de l'any 1550, tot i que molt probablement ja existia amb anterioritat. Està formada per una totalitat de dotze associacions, totes englobades sota una entitat que s'anomena Agrupació d'Associacions de Setmana Santa, creada l'any 1928. Moltes de les entitats són prèvies a aquesta agrupació. Les més antigues daten del 1353 (Gremi de Pagesos) i del 1383 (Gremi de Marejants). Com a curiositat, cal destacar que cap dels barris circumdants té una confraria pròpia i un d'aquests barris compta amb la seva Setmana Santa. Així doncs, el barri de Bonavista i la seva manifestació poden representar ben bé un clar exemple de la desconnexió que encara es percep avui en dia entre els barris circumdants i l'anomenat centre de la ciutat.

Moltes d'aquestes associacions tenen l'origen en grups gremials d'oficis (pagesos, gent del mar, espardenyers, corders, etc.). L'agrupació més novella és la del Cristo del Buen Amor y Nuestra Señora de la Amargura con San Juan Evangelista, que es va fundar l'any 1993. Aquesta és, sens dubte, una de les entitats més interessants a estudiar des d'un punt de vista antropològic, ja que majoritàriament és formada per immigrants andalusos que resideixen des de ja fa temps a la ciutat. Aquesta confraria, per tant, té algunes peculiaritats molt interessants que la vinculen amb una identitat andalusa i, readaptant el famós títol de Francesc Candel, podríem anomenar "els altres tarragonins". 
Malgrat que moltes d'aquestes confraries han perdut la identificació grupal fundacional - parlo de la gremial o la de socors mutus-, algunes entitats encara guarden una estreta relació i identificació amb sectors concrets com el del món de la mar i les confraries del Serrallo o el d'una escola en particular, la dels germans lasalians, més coneguda com La Salle.

Cada una de les entitats té un o més passos propis que o els porten a espatlles o els espenyen a rodes. La decisió de centrar-me tan sols en els portants a espatlles ha estat senzillament per una voluntat de delimitar al màxim possible la recerca. En cap cas vull desmerèixer l'esforç i la tasca que realitzen les persones que empenyen un pas. Tanmateix, en els portants a espatlles hi ha una variable a tenir en compte respecte a la resta de passos, i és el fet que requereix un fort compromís durant uns mesos abans de Setmana Santa per assajar i aconseguir una certa condició física.

Tarragona compta amb una totalitat de 21 escenes que representen diferents moments de la passió i mort de Jesucrist. D'aquestes 21, n'hi ha una que no va sobre cap peanya, el Sant Crist de la Sang, i una altra que no participa en la professó del Sant Enterrament de Divendres Sant (l'Entrada Triomfal). En resum, Tarragona té 12 passos duts a espatlles que necessiten fins a 245 persones aproximadament per portar-los.

Cal destacar que fins a finals dels anys setanta i principis dels vuitanta, els portants a espatlles eren antics estibadors remunerats per dur a terme aquesta tasca. Les disputes que cada any hi havia amb aquestes persones, que volien cobrar cada cop més, van portar que l'any 1983 germans voluntaris de les mateixes entitats decidissin atrevir-se a portar sobre el coll aquests passos amb l'ajuda d'algun casteller.

Entrem amb aquesta dada a una de les qüestions més interessants que avui dia encara podem constatar: una gran part dels portants dels passos estan o han estat vinculats a les colles castelleres de la ciutat. És per això que la Setmana Santa no només representa una tradició de devoció popular sinó que encarna un dels exemples més actius de la vida associativa de Tarragona.

Finalment, el fet que els portants originaris fossin estibadors del port comportava que la percepció social dels portadors dels passos estigués vinculada a la de l'home forçut. Aquesta dada, lluny de suposar una anèc- 
dota, ens traslladarà, junt amb els condicionants propis de la nostra societat patriarcal, a entreveure l'encara poca participació (que no vol dir absència) de les dones en aquesta tasca de portar els passos a coll.

\section{Identitats}

Lésser humà necessita identificar-se en moltes qüestions simbòliques $i$, encara que de vegades poden ser compartides amb altres persones, l'agrupament de cada una d'elles el defineix com un ésser únic amb unes particularitats o atributs que generen una autoclassificació que configura el que podríem anomenar la seva identitat.

Joan Prat (2013) distingeix diferents eixos i constants d'identitat entre els quals trobem: la identitat familiar, la local, l'ètnica i nacional, la de gènere, la generacional, la de classe o professional i la religiosa. Així doncs, tal com diu el mateix autor, podem entendre la identitat com:

Aquel principio, categoría, atributo y mecanismo de clasificación social que determina el lugar que ocupan los individuos y los grupos en su universo global. De esta forma, gracias a las marcas de identidad y a la aplicación del sistema de filiación o exclusión, podemos definir y situar el yo y el tu, el nosotros y el vosotros (o ellos) en el complejo mundo de interacciones biológicas, sociales, culturales o simbólicas en las que estamos inmersos.

Però a banda d'aquestes eixos fonamentals que abans anomenava, hem de destacar el que Berger i Luckmann (1997) defineixen com a institucions intermèdies, les quals, a més de donar sentit a les societats modernes que, segons els autors, pateixen crisis de sentit, també són fonts que en moltes ocasions configuren part de la identitat dels seus membres.

Així doncs, aquestes institucions o grups intermedis (Cucó, 1990: 153) són aquells que hi ha entre la família i l'Estat que no només es refereixen a associacions polítiques i econòmiques sinó també a aquelles de caràcter esportiu, festiu o religiós que, en el cas que ens ocupa, diríem que encaixen perfectament amb l'estructura de les diferents associacions que configuren la Setmana Santa tarragonina. 
Com a exemple de configuració de la pròpia identitat a través d'aquests grups intermedis de socialització, reprenc de nou l'etnografia digital a través de la xarxa social coneguda amb el nom de Twitter, en què l'elaboració del perfil d'una persona permet que s'identifiqui a la resta d'usuaris a través de la fotografia i d'un enunciat escrit. En el cas d'un informant d'aquesta investigació, hi podem llegir a la presentació del seu perfil: "Casteller de la Jove de Tarragona, membre dels Diables Voramar - Víbria de Tarragona, portant de l'Oració a l'Hort de La Salle i membre de Thaleia" (S.B.S.) $)^{5}$.

En aquest exemple, doncs, podem veure clarament una part de la configuració de la identitat per mitjà dels grups associatius que en l'exemple utilitzat també ens mostra una de les peculiaritats dels portants que ja esmentàvem anteriorment, que no és altra que la vinculació amb el món casteller o amb altres entitats culturals de la ciutat.

En les entrevistes realitzades, s'ha pogut observar que les identificacions més recurrents dels portants sobre la participació en la Setmana Santa, que tot seguit analitzarem, són les que fan referència a la religiositat (principalment la cristiana, tot i que no sempre vinculada a la institució eclesiàstica), a la família (tradició que passa de pares i mares a fills i filles) i a la ciutat, sobretot entesa en una concepció de ciutat, és a dir, de tarragonisme (en menor mesura alguna zona concreta de la ciutat). A banda, també analitzarem el gènere, com una categoria important d'identitat d'aquest collectiu.

Cal dir que aquestes etiquetes no són excloents entre elles, per la qual cosa hom pot sentir-se identificat amb una o amb més d'una.

5 Home de 40 anys, nascut a Tarragona, que fa deu anys que hi surt com a portant d'un pas de Setmana Santa. La participació li ve donada, principalment, per transmissió familiar. 


\section{Religiositat}

Reconèixer en la Setmana Santa de Tarragona múltiples motivacions que identifiquen els participants no significa, ni de bon tros, negar-hi el sentit religiós històric i original. Fonamentalment, les manifestacions processionals són una mostra pública d'un conjunt d'expressions plàstiques que rememoren els fets de la passió i mort de Jesús de Natzaret, el fill del Déu dels cristians.

Però també és cert que la vivència religiosa de la Setmana Santa pot tenir moltes variables i matisos significatius. Probablement, un nombre de participants important està configurat per un sector de la població que es defineix com a no creient i veu en aquesta manifestació la perpetuació d'una tradició i d'uns valors que caracteritzen una part de la cultura tarragonina (Muñoz, 2008: 227). Tanmateix, tal com es constata en les entrevistes, encara podem identificar un nombre important de persones que viuen aquesta manifestació des d'una religiositat cristiana que pot tenir uns nivells de pràctica molt variables.

En aquest sentit, podem trobar aquelles persones per a les quals la participació en les manifestacions populars de la Setmana Santa suposa una extensió més de la seva pràctica religiosa.

Doncs jo, en primer lloc, el pas el porto per una qüestió de fe, perquè jo sóc creient, catòlic i practicant [...] És una pregària, potser de les més intenses que sento. Penso... i com a pregària penso en totes les persones per les que vull demanar. Penso amb la gent que ho passa malament, penso amb la meva família, penso en els meus amics, penso en els meus companys, sobretot en els meus companys que no hi creuen... i potser no poden sentir el que puc sentir jo creient... (A.M.V.) ${ }^{6}$

Per a d'altres participants, la implicació en la Setmana Santa com a portants d'un pas suposa una extensió de la seva fe cristiana però d'una forma no adscrita a l'Església catòlica. D’alguna manera els podríem definir com a cristians creients, no practicants, que troben en les processons aquella eventual connexió mística i sentimental amb els seus particulars valors religiosos, sovint marcats per patrons culturals o familiars.

6 Home de 21 anys, nascut a Tarragona, que fa dos anys que participa en la Setmana Santa com a portant. Tot i que hi ha sortit des dels 9 anys, la participació no li va venir donada per transmissió familiar. 
Jo vinc de pares molt creients... però jo no sóc catòlic d'Església, no m’agrada anar a missa... No m’agrada no perquè no magradi el que diuen i el que fan sinó perquè... crec més en la intimitat [...] Lo que és la religió, o amb lo que és el sentiment de Déu, o de Jesucrist, o de tot això... això no ho he perdut mai! De fet, sí que és veritat que, quan passa algo a casa... Ostres... no em dona vergonya dir-ho però... és una cosa molt íntima... un Pare Nostre o un Ave Maria sempre surt. Sempre m'ha sortit! Sempre! Sempre! Sempre!" (O.G.G.) ${ }^{7}$

Pensant en aquest aspecte religiós, també hi trobaríem un perfil de persones que no es manifesten com creients però que respecten i reconeixen el cristianisme com una qüestió intrínseca en la nostra cultura. Sovint aquestes persones han tingut una educació cristiana que ve donada per transmissió familiar o bé per haver estudiat en una escola concertada gestionada per algun orde religiós.

Religiós no. No soc una persona que la religió formi part de la meva vida, ni soc una persona que transmeti la religió als meus fills, malgrat que van a un collegi religiós. Segurament els meus valors són els cristians, però no és una cosa que jo apliqui d'una forma racional, de dir: "jo faig això perquè sóc cristià..." o de dir: "actuo d'aquesta manera perquè sóc cristià..." (G.S.G.)

Però, sens dubte, una de les vivències més interessants en el terreny religiós és aquella que pràcticament engloba els tres perfils descrits, que té a veure amb el fet que el context i la posada en escena de la mateixa manifestació és una cosa que sovint colpeja vivencialment els portants dels passos. Descriuen moments de reflexió personal mentre estan portant el pas que denoten, en diferents casos, un cert aire del que podríem anomenar espiritualitat. És el que perfectament expressaven unes línies de l'opuscle de l'Agrupació d'Associacions de Setmana Santa de l'any 1930, que deien: "Una gran manifestació religiosa, capaç de commoure qui ja creu i d'excitar en l'incrèdul sentiments de respecte vers les nostres creences." En aquest sentit, alguns portants han explicat:

\footnotetext{
7 Home de 46 anys, nascut a Barcelona, que fa cinc anys que és portant d'un pas de Setmana Santa. La participació, en part, li va venir motivada per una religiositat no practicant.

8 Home de 40 anys, nascut a Tarragona, que en fa 22 que porta un pas de Setmana Santa. La participació li ve donada, principalment, per transmissió familiar.
} 
Jo crec que hi ha... hi ha moments personals que es viuen sota d'un pas de Setmana Santa que és complicat que es puguin produir en d'altres moments de la vida, o en d'altres llocs físics... moments de recolliment pues suposo que en pot tenir tothom a casa seva, a... pots anar a fer completes en una església o en un convent, tancar-te i allà hi ha recolliment... però la barreja que hi ha allà sota, entre els tambors, la gasolina dels ciris que crema, aquell crit d'ànim del company del costat, el "vinga xecs!"; bueno, crea com una atmosfera molt... molt personal amb la qual m'hi sento molt còmode o m'hi sento molt, molt a gust. (S.B.S)

Interiorment tens les teves reflexions, t'ajuden aquella tarda o aquella nit a... no sé... a tindre uns certs pensaments que potser en una altra època de l'any no els tens... no els tens... i això... t'incentiva a fer-ho... però portar-ho pel fet religiós... no!. (A.G.C.) ${ }^{9}$

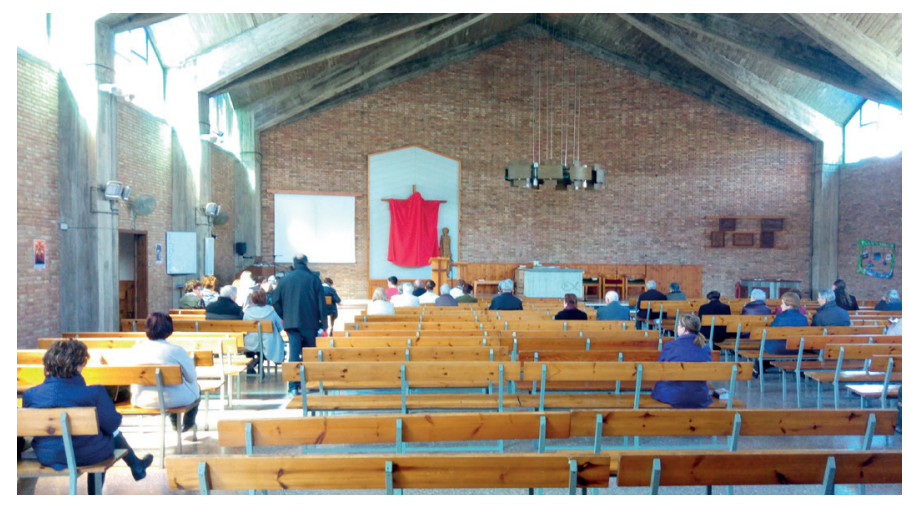

Aquesta imatge correspon a moments previs a la celebració de la litúrgia del Divendres Sant a l'església parroquial de Sant Pere i Sant Pau, on des de petit, i ara també, visc una part de la meva Setmana Santa. La celebració litúrgica és per a mi imprescindible, sense ella cap professó, cap tradició té sentit. La imatge de Crist tapat, que serà destapada en la Vetlla Pasqual, em recorda per què visc amb tanta intensitat aquest dia. Sense la seva passió no podem entendre la resurrecció de Jesús i, per tant, la seva celebració per part nostra, la festa més important de l’any per a un cristià. (A.M.V.).

9 Home de 54 anys que en fa 29 que porta un pas de Setmana Santa. És nascut a Tarragona i la participació li va venir motivada, sobretot, per formar part d'una altra entitat cultural de la ciutat, concretament, d'una colla castellera. 


\section{Família}

Tal com reconeixen investigadors de disciplines molt diferents, la família constitueix una de les categories socials més importants perquè, dins de la gran diversitat de models existents, ha esdevingut i esdevé el principal mecanisme de transmissió de les referències culturals i socials pròpies de cada societat.

Lluís Duch (2009), en els estudis sobre la codescendència, defineix la família com la primera "estructura d'acollida". Així doncs, la família és la primera estructura que introdueix l'ésser humà al món i, per tant, el primer mecanisme del que anomenem socialització o enculturació. És per aquest motiu que la Setmana Santa, allà on ha esdevingut un element de socialització dins d'una família i més enllà de la concepció religiosa, pot haver emergit com un factor d'identitat que s'ha transmès de generació en generació.

Doncs porto un pas de Setmana Santa perquè és el que jo vaig veure de petit a casa. A casa des de que vam nàixer som nazarenos... mon pare ens va fer nazarenos des de petits i hem viscut la germandat des de dins. Amb mon pare sent membre de junta, doncs vam viure totes les activitats de l'època que feia la germandat, doncs mon germà, mon cosí, amics hi érem... i d'alguna manera ha estat una cosa molt natural. (G.S.G.)

En conseqüència, la transmissió familiar en la Setmana Santa facilment la podríem entendre per la transmissió i participació dels ascendents familiars o, dit amb altres paraules, per filiació. Isidoro Moreno (1999), en un estudi sobre les confraries andaluses, ens diria que en aquests casos la participació ve donada per una "adscripción automática".

Però al llarg de les entrevistes s'ha constatat que aquesta transmissió familiar pot tenir diferents variables. D'una banda, trobem aquella transmissió que podríem anomenar participativa i que, com bé s'anomenava fa uns instants, respon a la participació activa dels familiars que fan que els portants es vinculin a la Setmana Santa per una vivència infantil molt propera.

D’altra banda, també trobem persones que, tot i que els ascendents no hagin tingut una vinculació participativa en alguna entitat de la Setmana 
Santa, sí que han sigut partícips com a espectadors dels diferents actes d'aquesta manifestació. Això ha comportat que, amb el temps, hagin volgut adherir-s'hi com a record de vivències infantils o per vinculació amb alguna altra associació o amic que sí que hi participa; és el que podríem anomenar la transmissió familiar per les manifestacions populars.

Finalment, hi trobem aquells portadors que no hi han participat ni com a espectadors ni l'han viscut de petits, però s'hi han acostat per una transmissió familiar de la religiositat cristiana, és a dir, com una extensió més de les seves creences.

La importància social de la família és un fet tan determinant que no és estrany que molts dels portants manifestin que bona part de les reflexions personals durant els moments que porten el pas vagin lligades als familiars actuals o passats, o bé que els llocs més emblemàtics del recorregut processional siguin aquells on hi ha la família mirant.

Però el lligam de la Setmana Santa amb l'àmbit familiar no només té relació directa amb les processons del carrer i amb la religiositat sinó també amb la celebració d'un temps de festa i, en conseqüència, amb un temps que es comparteix amb la família.

Qualsevol festa (sigui de caire més alegre o de recolliment) és una mostra clara que el temps humà és heterogeni i molt sovint aquests temps festius són espais habitualment dedicats al retrobament i la reunió familiar. L'exemple més clar el trobem en les festivitats nadalenques, però no hem d'oblidar pas que en la nostra cultura la Pasqua o les festes majors en poden ser un altre exemple.

Sí, sí... com a tradició el Divendres Sant sempre dinem a casa mons pares, tant ma germà com jo... perquè bueno, ja hi dinàvem de joves $i$, des de que vam marxar a viure fora, cadascú a casa seva, el Divendres Sant sempre dinem junts... això sí... llavors des d'allà cadascú comença el seu Divendres Sant particular... (S.B.S.)

D’aquesta manera, tal com ens diu Lluís Duch (2009: 161), malgrat que la festa pot tenir un caràcter més o menys laic, en les festivitats familiars sempre hi haurà alguna cosa que tindrà ressonàncies religioses (el temps festiu és un temps separat i, per tant, un temps sagrat, ja que per mitjà dels rituals suposa una oportunitat de regeneració social i cons- 
trucció de la vida comunitària). En aquest sentit, el mateix autor destaca tres aspectes claus de la celebració de la festa en família:

- La relligació (religare), que es refereix a la vinculació implícita o explícita entre els membres d'una família que celebren una determinada festa que no només mostra els vincles que hi ha entre ells en el present sinó també amb tots els que els han precedit.

- La festa com a reactualització de la família, és a dir, un "tornar a llegir" (relegere) la realitat familiar en un espai i un temps determinats i en unes circumstàncies determinades (afinitats, rivalitats, confrontacions, simpaties, etc.).

- La celebració de la festa com un presa de decisió de continuar o no continuar les relacions familiars, és a dir, com a sinònim de continuïtat o de ruptura. Seria un "tornar a escollir" (re-elegere). En aquest sentit, Duch ens recorda que moltes de les ruptures en el si d'una família tenen com a punt de partida les festivitats familiars. Aquest concepte de la reunió familiar és el que fa que moltes persones emigrants retornin per Setmana Santa als seus pobles natius amb l'objectiu de participar en aquesta manifestació com a símbol de retrobament familiar i, com veurem més endavant, com a símbol d'identitat territorial. Aquest és un exemple clar de molts andalusos que viuen a Catalunya i retornen a la seva terra durant aquest període. Un dels portants entrevistats, d'origen cordovès, comentava el següent:

Ya te digo, la Semana Santa la viví de niño en el pueblo... después cada año íbamos a la Semana Santa... la fiesta realmente que nos gustaba hacer era la de la Semana Santa... Se juntaba la familia... pero sí es verdad que los Viernes Santo es como el día de Navidad... en familia. (M.G.G.. ${ }^{10}$

10 Home de 58 anys nascut en un poble d'Andalusia que fa cinc anys que hi participa com a portant d'un pas de Setmana Santa. Va començar a sortir per la voluntat de formar part del teixit cultural de la ciutat, més concretament d'un barri. 


\section{Territori}

Actualment no podem parlar d'identitats territorials sense entendre o contextualitzar el procés de globalització en què es troba immers el món, sobretot el món que anomenem occidental.

Els fluxos migratoris propicien el contacte cultural que, tal com ens deia Lévi-Strauss (1979), fan emergir la consciència de la diferència. D’aquesta forma podríem dir que la Setmana Santa no només és religió o tradició; és també un fenomen d'identificació local davant la diferència, i, en conseqüència, com a resposta als processos de la globalització.

Així doncs, tal com expressa Garcia Canclini (1990: 200), moltes cultures populars, a través de les manifestacions al carrer, en lloc de desaparèixer, s'han transformat amb l'objectiu de reivindicar una pertinença al lloc. A més, és important tenir en compte que, a causa d'aquest potencial d'identificació, la gran majoria són patrocinades per les administracions públiques i les grans empreses com un reclam turístic i publicitari.

Quan porto el pas no només l'estic portant jo, sinó que estic representant unes persones, una entitat, una ciutat i que hi ha molta gent que ve a veure una Setmana Santa que li han explicat que és d'una determinada manera i, d'alguna manera, em sento amb l'obligació de comportar-me d'aquesta manera. (G.S.G.)

En aquest sentit, doncs, hi ha molts portants que participen en la Setmana Santa allunyats de l'esperit religiós per reivindicar la seva pertinença a la ciutat d'alguna manera. Tanmateix, cal aclarir que participar-hi amb un sentit d'identitat territorial no exclou, com ja s'ha dit anteriorment, la identificació amb altres categories que s'han anomenat, com la familiaritat o la religiositat.

En moltes de les entrevistes mantingudes, els informants s'han referit al concepte fer tarragonisme com una forma més de participar en actes populars que identifiquen la ciutat. En aquest sentit, podríem dir que seguir amb les tradicions pot ajudar a identificar-se amb la cultura, amb els orígens i, per tant, amb la ciutat. També pot ser un mitjà d'integració. De fet, la qualificació de popular ja suposa que la participació del poble és un dels eixos fonamentals en els quals s'hi ha de veure reflectit. 
És per aquest motiu que en nombroses ocasions, quan es critica algun aspecte de la Setmana Santa tarragonina, és en relació amb la pèrdua o l'aparició d'elements que no hi són originaris. En aquest sentit, la introducció de bandes de música amb percussió típica d'altres zones de l'Estat espanyol és una cosa que, segons algunes opinions, ha fet perdre identitat.

El malestar ve de que tradicionalment a Tarragona les bandes eren bandes de música que acompanyaven els passos... excepte a algun molt puntual... i això ha desaparegut del mapa... ara per exemple, el Vetlleu i Pregueu continua anant amb una banda, però són molt poques puntuals [...] I ara s'ha instaurat un tipus de so que no és propi del Camp de Tarragona, que és propi de la ruta del tambor... que és molt lloable! Però... el que ha fet això és que el que era tradicional aquí hagi desaparegut quasi... (S.B.S.)

Cas a banda i no exempt de polèmica en aquest sentit fou l'aparició de la Confraria del Cristo del Buen Amor, més coneguda popularment com la dels andalusos. Aquest cas, però, que mereixeria una atenció digna i acurada, pot suposar dues tipologies d'identitat territorial. D'una banda, la identificació amb els orígens familiars, Andalusia, i de l'altra, una voluntat de reivindicar-se com uns tarragonins més.

De les paraules d'un informant que manifestava que Tarragona i moltes altres ciutats es converteixen en Jerusalem el Divendres Sant, certament en podríem dir que l'acte simbòlic que rememora uns fets és global. Però el cert és que, si analitzem detalladament cada una de les manifestacions populars mundials, podrem reconèixer-hi trets d'identificació territorial molt concrets. En altres termes, veurem que no és el mateix la Setmana Santa d'Hondures que la de l'Estat espanyol, i que dins d'aquest, no és igual l'andalusa que la catalana, i si encara hi aprofundim més, que no és la mateixa la de Valls que la de Tarragona.

És per això que molts símbols que identifiquen Tarragona seran presents en la Setmana Santa i en els portants per mitjà del color blau que representa el mar, els mocadors dels castells lligats a les faixes dels portants, la tau tarragonina, les espardenyes de pagès, etc. Tampoc hi faltarà la presència jeràrquica de l'Església, les autoritats polítiques i les grans 
empreses petroquímiques en la publicitats dels opuscles o els cartells. En definitiva, un reflex de la societat tarragonina.

Però com sempre que fem una afirmació d'aquestes característiques, caldria preguntar-nos: quina Tarragona reflecteix la Setmana Santa? Mn. Salvador Ramon ens n'aportava alguna petita pista quan deia: "La Setmana Santa és la gran festa major de la ciutat antiga. Les generacions s'han anat passant la torxa de les tradicions i el drama del calvari té en ella una versió especial." En aquest sentit, podríem dir que el fet que sigui una tradició de la ciutat antiga i que Bonavista tingui una professó pròpia, ens fa pensar ràpidament en una Tarragona desvertebrada territorialment, que no aconsegueix amb la Setmana Santa la vivència global de ciutat que es pot percebre en altres manifestacions populars com el Carnaval, on els barris circumdants sí que tenen presència al centre de la ciutat.

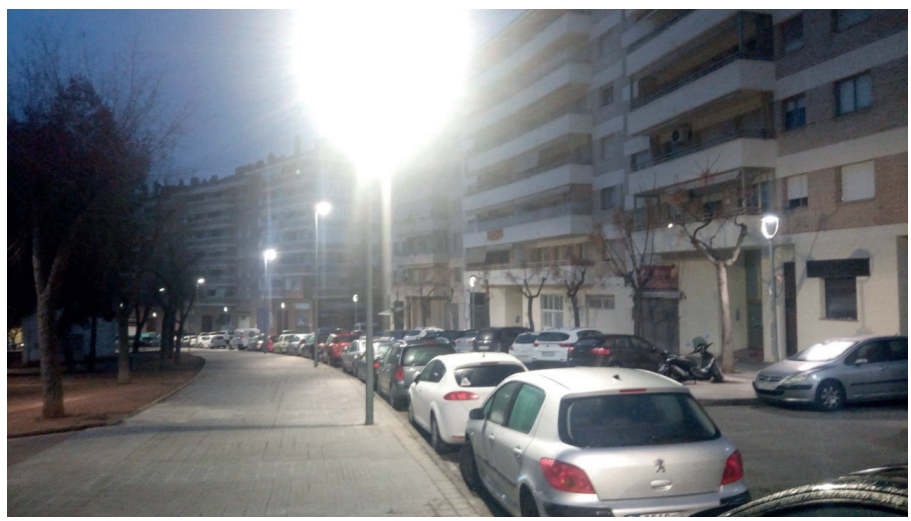

El meu barri, Sant Pere i Sant Pau, un diumenge a les 6 del matí abans d'anar a un assaig del misteri. En aquests instants, al portal de casa i al cotxe, recordo com celebrava la Setmana Santa abans de ser natzarè, quan era escolanet de la parròquia del barri. Tot el sentiment que em fa viure la Setmana Santa amb tanta intensitat ha nascut al barri, de la mà dels meus avis paterns, dels meus pares i de la meva comunitat parroquial. La Setmana Santa que visc al centre de Tarragona no deixa de ser una extensió del que visc a Sant Pere i Sant Pau. Si deixés de viure la del barri, deixaria una part de mi i de la meva Setmana Santa, que considero igual d'essencial com el fet de ser natzarè. (A.M.V.). 
Arribats a aquest punt, ens preguntaríem: quins adjectius caracteritzen la professó de Tarragona? Tot i que ha estat coneguda popularment com la del "silenci", tal com es deia més amunt, ha anat perdent aquesta característica a causa de la proliferació de bandes de timbals que, si bé n'han modificat part de la idiosincràsia, també han contribuït a incrementar-ne la participació. Tanmateix, alguns portants han qualificat la Setmana Santa de Tarragona sota els adjectius d'austeritat, seriositat, humilitat i de manifestació continguda.

Per acabar aquest aspecte de la identitat territorial, cal dir que, malgrat que majoritàriament el que es reivindica és una pertinença local, és a dir, una pertinença a la ciutat de Tarragona en general, encara hi ha certes identificacions més específiques, a banda de la ja esmentada dels andalusos, que responen a la pertinença a algun barri, com seria el cas del Serrallo a través del Gremi de Marejants o de la Confraria de Pescadors; identificacions relacionades amb una parròquia, com seria el cas de la Germandat de Nostre Pare Jesús de la Passió, més coneguda com la de Sant Joan en allusió al nom de la seva comunitat parroquial; identificacions de gènere, com la Congregació de Senyores de la Mare de Déu de la Soledat, formada exclusivament per dones, o bé identificacions relacionades amb una escola, com seria el cas de l'Associació La Salle.

\section{Gènere}

En l'àmbit de la religiositat popular, més concretament en la Setmana Santa, l'espai privat ha estat preferentment reservat al gènere femení, el qual, a l'ombra de l'exhibició pública de l'home, que principalment ha adoptat un paper de més protagonisme al carrer, sovint s'ha encarregat de planxar i cosir els vestits, cuinar les receptes tradicionals dels dies de Quaresma, o bé netejar (FERNÁNDEZ, 2018: 58).

No és que malauradament la repartició d'aquests rols hagi desaparegut de manera definitiva, tot i que podem afirmar que la Setmana Santa està vivint canvis importants en aquest sentit. Així doncs, la presència de dones en collectius com el dels portants, les bandes o, fins i tot, en càrrecs presidencials de les entitats, és un fet que, encara que minoritari, 
cada cop és més present i habitual en el context d'aquesta manifestació popular.

Cal no oblidar que fins a principis dels anys vuitanta, la presència de les dones havia estat vetada a les professons i se'ls reservava el paper en l'esfera privada al qual abans ens referíem. Fins llavors l'única oportunitat de participar-hi era a través de l'anonimat dins el collectiu dels penitents o bé a través de la Mare de Déu de la Soledat.

Però un cop trencada aquesta prohibició, la Setmana Santa va viure, i viu, una explosió de participació fins al punt que, sense la presència de les dones, les processons esdevindrien manifestacions minoritàries. Com bé apunten molts entrevistats, segurament aquest impuls que les dones ha donat a la Setmana Santa és un fenomen que bé podríem traslladar a altres collectius populars que també han viscut un creixement exponencial, com és el cas de les colles castelleres.

Els passos a espatlles són diferents si vas de ganxo o si vas dins... jo no he anat mai a dins, però les vegades que ens hem posat en broma a dins, et dones compte de que... tens un pes a sobre i que thas de dedicar a aguantar-lo [...] Bàsicament la teva feina és portar pes, no? Llavors sí, les dones poden aguantar aquell pes sobradament, igual que un home, igual que les dones poden anar de crossa als castells [...] o aguanten tot una cercavila de festa major portant la Mulassa o portant qualsevol altra imatge... (S.M.F.) $)^{11}$

Però el que ens interessa analitzar en aquest article no és exclusivament els canvis històrics que s'han produït respecte a la participació de les dones, sinó també l'actual paper d'elles dins el collectiu dels portants a espatlles. Per fer-ho, caldrà tenir en compte el concepte tradicional de la masculinitat, que seria aquell que va lligat a certs valors com la força física com a màxima expressió de virilitat. Amb tot, cal especificar que la construcció del gènere i els valors que s'hi afegeixen és una qüestió cultural i, més específicament, occidental. Un informant deia: "No és el mateix veure un misteri portat per quatre homes forts i robustos que per tios que veus que quasi van penjats del misteri." (A.M.V.)

11 Home de 28 anys que en fa onze que hi participa com a portant. La vinculació al pas li va venir donada, principalment, per transmissió familiar. 
Ja s'ha comentat en la introducció que el fet que els estibadors del port s'encarreguessin de portar els misteris és una cosa que, durant molt de temps i lligat a la concepció tradicional de la masculinitat, ha propiciat una presència menor de la dona en aquest collectiu pel fet de pressuposar-li, ja de per si, una condició física menor.

En les entrevistes realitzades s'ha pogut detectar com, fins i tot en el moment de la transició dels portants portuaris als portants voluntaris, es tingueren molts dubtes que aquells homes que, comparats amb els estibadors, estaven poc acostumats a carregar pes en les seves tasques professionals, fossin capaços de portar els passos al coll.

Així doncs, la concepció del portant habitualment ha anat lligada als tradicionals valors masculins que estan vinculats a la capacitat física $i$ que, de mica en mica, tal com passa en el collectiu casteller, es van desmitificant, tot i que això no signifiqui que hagin desaparegut.

En el cas de la investigació, majoritàriament tots els portants han expressat en les entrevistes la conformitat que les dones hi participin com a portants, malgrat que cal tenir en compte certs matisos d'algunes persones que encara deixen entreveure una concepció del portant lligada als valors masculins tradicionals. És el cas, per exemple, de mostrar conformitat amb la participació de les dones i pensar, quasi de seguit, que ella pugui ocupar les posicions dins el pas que requereixin carregar menys pes o trams del recorregut que demanin menys intensitat.

Poses a una noia a portar el pas amb les mules que nosaltres portem amb el pas... doncs s'ho passarà malament... Si porta el pas amb els ganxos, que tenen un estil més solemne, més discret de portar el pas... discret no ho dic com menys, eh! Dic que és un altre estil de portar-lo més discret, que llueix molt en determinades zones de la professó... Doncs segurament aquestes noies tindran aptituds per portar el nostre pas... i evidentment a dins, jo crec que, mentre tinguis capacitat de patir, d'aguantar... sí, clar!" (G.S.G.)

Possiblement, encara que no sempre, la diferència d'edat fa que hi hagi portants que s'identifiquin amb una masculinitat més propera a l'estereotip tradicional que no pas els joves educats amb altres valors. 
La societat actual, però, cada cop més ens presenta un home en mutació constant que, en conseqüència, propicia canvis en la idea de gènere. Així doncs, davant de la construcció social del portant fort, que va lligada a un ideal de masculinitat, s'ha pogut observar dins d'aquest collectiu determinats valors popularment associats a la feminitat com podrien ser el fet d'emocionar-se públicament tot realitzant mostres d'afectuositat als companys.

Per tant, en un grup de portants hi podem trobar qualitats, valors i expressions que reprodueixen el model de masculinitat hegemònica junt amb característiques representatives i pràctiques que tradicionalment han estat considerades femenines. Malgrat aquests canvis, molts portats encara reprodueixen, en diferents ocasions, les qualitats denominades masculines com una manera de justificar la seva tasca. Un exemple en seria el fet de mostrar amb orgull les marques al cos provocades pel pes del misteri sobre les espatlles (vermellors o altres senyals que apareixen per l'impacte sobre el cos de l'estructura que es duu a coll).

\section{Identitat de grup}

Fins al moment hem parlat de diferents processos d'identitat que podríem definir com a particulars (família, religió, gènere i localitat); és a dir, que, malgrat que poden ser compartits amb altres companys, cada portant pot sentir-se identificat o no amb la totalitat dels mateixos companys o només amb una part. Però d'entre els processos d'identitat dels portadors, n'hi ha un que el podríem considerar global, que generalment és compartit per la totalitat dels membres de cada col-lectiu de portants i no és altre que el de la consciència de grup, el del sentiment de pertinença a un col-lectiu.

La Setmana Santa en general, i les relacions del collectiu de portants en particular, estan plenes de rituals, formals i informals, que proporcionen una forta identitat de grup. És en aquest sentit que molts portants s'han referit al grup qualificant-lo com una gran família. De fet, si ens paréssim a analitzar la nomenclatura d'algunes entitats de la Setmana Santa, veuríem que s'utilitzen noms que designen parentiu com germandat. 
Però retornant de nou als portants i a les relacions que s'hi estableixen, les vivències sota el pas i els llaços de fraternitat poden arribar a ser tan significatius que en alguns casos, quan algun portant ha mort, s'ha establert un ritual per retre-li una mena d'homenatge que, fins i tot, podríem qualificar de certa espiritualitat. Un dels portants entrevistats expressava:

O l'any que... que vam pujar la pujada, a la recollida de passos... la vam fer a pas lent perquè se'ns havia mort l'ex-cap de colla... i clar... tothom aplaudint i d'això... i reconec que... uf! és d'aquells moments que dius: hosti! m'està passant algo i no sé què és.... Però... buf! estic sentint algo que cada Divendres Sant no ho sento... (S.B.S.)

Però si t'hi fixes... estic parlant de sentiments, però no cap al fet religiós sinó que estic parlant de sentiments cap a dues persones, no?... Vull dir que aquí a vegades... que aquí el fet religiós no sé si tindria molta cabuda... T'emociones però no pel fet de que estàs portant a dalt una imatge de Nostre Senyor allà a l'Hort de les Oliveres... demanant forces... no! sinó per la vivència personal que has tingut amb un company. (S.B.S.)

Però per analitzar les relacions que s'estableixen entre els portants, cal tenir en compte els conceptes de communitas i liminaritat que va descriure Victor Turner (1988). Per a aquest antropòleg, les societats estan compostes per una estructura social que en determinats moments es converteix en el que ell anomena communitas. La primera faria referència a una estructura jerarquitzada íntimament lligada a la propietat, és a dir, a un sistema de posicions socials. La communitas, en canvi, és el moment i l'espai social en què les lleis jeràrquiques de l'estructura es difuminen fins a desaparèixer.

D’alguna forma, el que ens vindria a dir la communitas és que tots els membres de la societat són iguals; un concepte que, si el relacionem amb l'anàlisi dels portants de la Setmana Santa, se'ns presenta amb una evidència clara. En moltes de les entrevistes mantingudes, els informants han manifestat la convicció que, sota el pas, tots els companys, independentment de la professió, els estudis o la posició social, són iguals.

La Setmana Santa és un fet popular... és una cosa que és popular! Però popular no vol dir folklòric, vol dir popular, que la fa la gent del poble... 
i la gent del poble són polítics i són pescadors... Són gent d'entitats econòmiques macro i són el petit botiguer del carrer Major o del carrer Canyelles o del carrer la Unió... (G.S.G.)

Et sents a gust, et sents còmode... és un grup absolutament amb una diversitat de perfils i de persones... però jo crec que és el gran encant, no? i d'ideologies, no? Allí parlem de tot, no? i... bueno, però ens uneix tot... que és portar un pas, i a més portar-lo bé i fer-ho bé, no?" (J.A.F.) ${ }^{12}$

Turner ens diu que en tota societat hi ha d'haver un equilibri entre l'estructura i la communitas, ja que en cas contrari les tensions socials podrien arribar a ser insuportables. D'alguna forma, aquest concepte el podríem relacionar amb el temps de festa, del qual s'ha parlat en l'apartat de la identitat familiar, que va lligat a la concepció que el temps és heterogeni.

Però per entendre com entra en acció la communitas, és necessari entendre el concepte de liminaritat, que Turner defineix com una de les fases dels ritus de pas que prèviament havia descrit Van Gennep (citat a TURNER, 1988). En aquest sentit, hi hauria dues tipologies de ritus de pas: en primer lloc, aquells pels quals un subjecte passa a formar part, d'una forma irreversible, d'una altra posició social (per exemple, el pas de la infantesa a l'adolescència) $i$, en segon lloc, aquells rituals, com la Setmana Santa, que van lligats cíclicament al calendari anual. En aquests darrers, és on es produeix d'una forma evident aquesta difuminació de les jerarquies. El Carnaval en seria, l'exemple més rotund amb la inversió de les jerarquies, però la Setmana Santa i el collectiu de portants en seria un altre que, malgrat que no suposa una inversió social, sí que és un exemple d'igualtat.

Així doncs, el collectiu de portants, a través dels rituals cíclics en el calendari, representa una communitas perquè en la seva tasca no hi ha jerarquització social i tots els membres passen a tenir les mateixes condicions. D'aquesta forma, tal com diu Morales (2012: 183): "La fraternitat, viure en una família àmplia dies festius, especials, compartir àpats, projectes, esborrar barreres socials que existeixen a fora, l'experiència de la communitas, provoca benestar, plaer, comunió."

12 Home de 52 anys que en fa quinze que hi participa com a portant. La vinculació va produir-se, principalment, per amistat amb una altra persona que era portant. 
Dins de la vida del portant, hi ha una sèrie de rituals a través dels quals es potencia la socialització i, en conseqüència, s'enforteixen els vincles tot creant una forta identitat de pertinença al grup. Són els esmorzars, reunions i assajos dels dies previs i dels dies de professó.

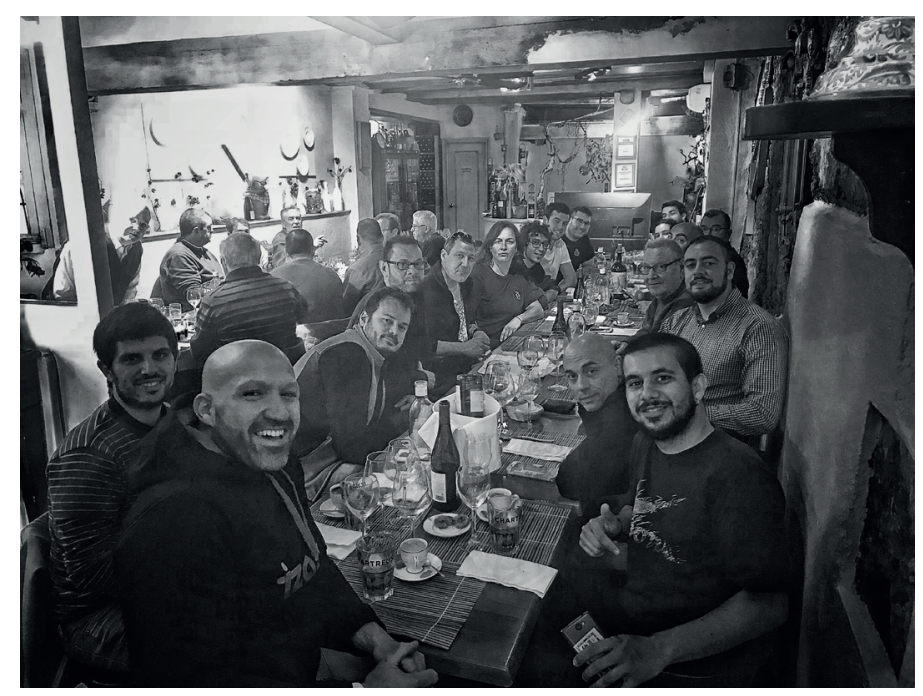

L'esmorzar de Divendres Sant és un moment que comparteixo amb els meus germans natzarens i companys portants abans d'afrontar la processó de la tarda. Un cop s'acaba aquest esmorzar, tot passa molt ràpid. La missa, la recollida dels passos i la processó. Divendres Sant és un dia frenètic en el que l'esmorzar representa un moment de calma i distensió. (A.M.V.).

\section{Conclusions}

La manifestació popular de la Setmana Santa és un ritual que, dins el calendari anual, ofereix un trencament de la vida quotidiana, una constatació que el temps humà és heterogeni. La repetició cíclica esdevé així, una acció tradicional en forma de celebració festiva i, com a tal, un element per mitjà del qual un pot adherir-s'hi sota múltiples processos d'identificació. 
Indiscutiblement, com en molts rituals de la nostra cultura, l'origen té un simbolisme religiós, més concretament cristià; però les transformacions religioses dels temps actuals, que alguns defineixen sota el terme modernitat, han propiciat que el cristianisme, i sobretot la màxima institucionalització d'aquesta confessionalitat, l'Església, ja no marquin les pautes de funcionament social.

Però, com hem pogut comprovar, els rituals d'origen religiós, com la Setmana Santa, són polisèmics, ja que no només comuniquen missatges relacionats amb allò sobrenatural sinó també amb allò econòmic, social, lúdic, ètnic o cultural entre d'altres. En definitiva, podríem dir que són un reflex de la societat en què estan emmarcats i, per tant, una manifestació que va més enllà del seu sentit religiós. És el que podríem dir, utilitzant el concepte proposat per Marcel Mauss (1971), un fet social total.

Se expresan a la vez y de golpe todo tipo de instituciones: las religiosas, jurídicas, morales -en estas tanto las políticas como las familiares-y económicas, las cuales adoptan formas especiales de producción y consumo, o mejor, de prestación y de distribución, y a las cuales hay que añadir los fenómenos estéticos a que estos hechos dan lugar, así como los fenómenos morfológicos que estas instituciones producen."

És en aquest sentit que, com a fet social total, la Setmana Santa es manté viva com una reproducció d'identitats que es mouen des de la individualitat de les creences religioses, la familiaritat o la pertinença a un territori fins a la vivència en communitas d'un sentiment d'adhesió a un collectiu de gent que, a través de rituals de diferent naturalesa, creen un forta identitat de grup.

En els ambients de la Setmana Santa, sovint es parla amb preocupació del descens de participació de la gent a les fileres laterals que illuminen amb les tradicionals atxes els passos, bandes i estendards que desfilen al centre de la comitiva processional. Certament, a simple cop de vista no els falta raó i encara menys quan aquestes percepcions són acompanyades de dades estadístiques.

Però si tenim en compte l'anàlisi dels portants, ens podem adonar que, precisament, una de les principals característiques d'ells enfront de la vivència dels encaputxats de les files és el sentiment de pertinença a un 
collectiu amb el qual durant molts dies s'han compartit vivències i anècdotes vàries que culminen en un treball collectiu en què tots els membres se senten partícips i es troben en una situació social d'igualtat.

Aquest sentiment de pertinença, a més, té un doble sentit de relació amb el temps. Els portants, per norma general, ho són durant molts anys si les condicions físiques i personals els ho permeten, però els moments en què s'experimenta el sentiment de pertinença és un temps que, si bé es repeteix anualment, és limitat durant unes setmanes prèvies a la Setmana Santa.

Ara bé, com han traslladat diferents portants, la sensació que es viu carregant un pas de Setmana Santa té alguna cosa d'inexplicable per l'aura del context. La posada en escena de la professó té certament un efecte colpidor en el participant i en l'espectador. Els carrers estrets i freds de la Part Alta es tornen càlids amb la llum de les atxes, els tocs de tambor i el silenci dels penitents fan esborronar la pell, la respiració dels companys i la suor de l'esforç són condicionants suficients per fer d'aquesta pràctica una experiència molt particular.

I com que aquesta recerca està emmarcada en la Universitat Rovira i Virgili, no podria tancar aquest article sense les paraules de l'illustre personatge que dona nom a la institució (citat a Ramon, 1994: 91-92):

Us diré la veritat; de la processó me’n recordo molt; però la meva visió de la Setmana Santa tarragonina és la visió dels voltants de la ciutat en aquestes diades primaverals amb sol esplèndid, amb mar i cel nets, blavíssims, amb arbres en flor, amb sentor d'aquelles tres herbes - farigola, romaní i espígol- que fan "olor de Tarragona”... Allò que jo més estimava d'aquests dies, era el silenci, la quietud, la soledat, l'ambient de meditació. Assegut en alguna pedra dels corriols que pugen per les tossals circumdants, sentia dins de mi, enmig de l'isolament exterior, totes les veus de la meva ànima, i sobretot les veus profundes que només sentim quan els sorolls de fora s'apaguen. Mai, com en aquells moments, no he vist tan noble i pura ni alta la vida de l'home, mai no he vist tan bella la naturalesa. I un lleu regust de melangia feia encara, per a mi, més amades aquelles hores de recolliment... Tornava a la ciutat quan s'acabava de fer fosc, i aleshores veia resplendir amb vermellors d'incendi la 
processó del Sant Enterrament, i sentia el cop feixuc de les llances dels soldats romans, el cop dels timbals de la cohort cobert de tant en tant pel toc de trompeta que anuncia les passades, el fort trepig dels cavalls de l'escamot de la guàrdia civil que obria la marxa... La processó ja s'havia dissolt, i a mi em quedaven, fortament impreses en la meva ment, dues imatges predominants: els carrers vermellejant al pas de les rengleres d'atxes, i la palma argentada del Sant Sepulcre movent-se amb tràgica tremolor" (A. Rovira i Virgili, 1949).

\section{Bibliografia}

Berger, P. i Luckmann, T. (1997). Modernidad, pluralismo y crisis de sentido. La orientación del hombre moderno. Barcelona: Paidós.

Cucó, J. (1990). "El papel de la sociabilidad en la construcción de la sociedad civil”. A: Cucó, J. i Pujadas, J. J. (coord.). Identidades colectivas. Etnicidad y sociabilidad en la Península Ibérica. València: Generalitat Valenciana.

Duch, L. i MÈLICH, J. C. (2009). Ambigüedades del amor. Antropología de la vida cotidiana 2/2. Madrid: Trotta.

Fernández Angulo, P. (2008). "Espacio y género en las trabajaderas". Opuscle de la Reial Germandat de Jesús Natzarè.

Garcia CANCLINI, N. (1990). Culturas híbridas. Estrategias para entrar y salir de la modernidad. Mèxic: Grijalbo.

GarCía Pilán, P. (2010). Tradición en la modernidad avanzada: la Semana Santa Marinera de Valencia. València: Diputació de València. Museu Valencià d'Etnologia. Col-lecció Intercanvis.

Lévi-Strauss, C. (1979). Antropología estructural. Mito, sociedad, humanidades. Madrid: Siglo XXI.

Mauss, M. (1971). Sociología y antropología. Madrid: Tecnos.

Moreno Navarro, I. (1999). Las Hermandades Andaluzas. Una aproximación desde la antropología. Sevilla: Universidad de Sevilla. Secretariado de Publicaciones.

Moreno Navarro, I. (2006). La Semana Santa de Sevilla. Conformación, mixtificación y significaciones. Sevilla: Instituto de la Cultura y las Artes. Biblioteca de Temas Sevillanos. 
Muñoz Melgar, A. (2008). "La Setmana Santa de Tarragona des dels ulls de la fe cristiana”. A: Mas CARCEller, Q. et aliï. Setmana Santa a Tarragona. Imatges i paraules. Tarragona: Arola Editors.

PRAT Carós, J. (2013). "Identidades: una perspectiva antropológica”. A FERRERO, R. (coord.). Conversaciones antropológicas. València: PUV. Universitat de València.

Ramon Vinyes, S. et alii (1994). Introducció a la Setmana Santa de Tarragona. Tarragona: Virgili Editors. Biblioteca Tarraconense 9.

SuÑÉ MoRAlEs, J. (2012). "Jo sóc armat. Reivindicant la identitat cristiana i local”. Arxiu d'Etnografia de Catalunya (12).

Turner, V. W. (1988). El proceso ritual. Estructura y antiestructura. Madrid: Taurus. 